\title{
Hydrogeophysical Investigation for Groundwater Resources from Electrical Resistivity Tomography and Self-Potential Data in the Méiganga Area, Adamawa, Cameroon
}

\author{
Meying Arsène $\mathbb{D}^{\mathbb{D}},{ }^{1}$ Bidichael Wahile Wassouo Elvis, ${ }^{2}$ Gouet Daniel, ${ }^{3}$ \\ Ndougsa-Mbarga Théophile $\mathbb{D}^{2,4}$ Kuiate Kelian, ${ }^{1}$ and Ngoh Jean Daniel ${ }^{2}$ \\ ${ }^{1}$ School of Geology and Mining Engineering, University of Ngaoundéré, Ngaoundéré, Cameroon \\ ${ }^{2}$ Postgraduate School of Sciences, Technologies \& Geosciences, University of Yaoundé I, Yaoundé, Cameroon \\ ${ }^{3}$ Department of Petroleum, Mining and Groundwater Resources Exploration, \\ Faculty of Mines and Petroleum Industries, University of Maroua, Maroua, Cameroon \\ ${ }^{4}$ Department of Physics, Advanced Teacher's Training College, University of Yaoundé I, Yaoundé, Cameroon
}

Correspondence should be addressed to Meying Arsène; arsenemeying@yahoo.fr

Received 10 April 2018; Accepted 25 June 2018; Published 25 July 2018

Academic Editor: Sándor Szalai

Copyright (c) 2018 Meying Arsène et al. This is an open access article distributed under the Creative Commons Attribution License, which permits unrestricted use, distribution, and reproduction in any medium, provided the original work is properly cited.

\begin{abstract}
Exploration and production of groundwater, a vital and precious resource, is a challenging task in hard rock, which exhibits inherent heterogeneity. A geophysical survey was conducted in Méiganga, Mbéré department, in the Adamawa region, Cameroon. Highresolution electrical resistivity tomography (ERT) and self-potential (SP) dataset were collected in a gneissic terrain to solve the groundwater problem as people are facing acute shortage of drinking water in the study area. The analysis and interpretations based on resistivity models revealed substantial resistivity contrast between the altered gneiss that might contain water and massive gneiss and delineated five deeper groundwater prospects zones located at Yelwa, Ngoa-Ekélé, Sabongari, Ngassiri, and Gbakoungué, respectively. Nevertheless shallow groundwater zones $(<13 \mathrm{~m})$ are located in the northern part of the study area at high elevation while best prospect and productive groundwater zones lying between 20 and $25 \mathrm{~m}$ depth are at low elevation in the southern part. On the other hand, analysis of SP negative peaks along with groundwater head and groundwater vector maps revealed areas of recharge and discharge across the study area. The discharge areas serve as groundwater collection center and are good groundwater potential zones. In addition these maps revealed that groundwater flow pattern shows inward flow from the flanks to center and south central parts of the study area.
\end{abstract}

\section{Introduction}

Water is the main source of life on Earth. It is abundantly supplied by nature. But access to this resource in good quality and quantity is difficult and decreases at a very fast pace [1]. Thus the supply of water of good quality in sufficient quantity of urban and periurban centers, in order to respond to need of populations and ecosystems with unregulated urbanization fueled by population growth and internal migration, remains one of the major challenges of the 21st century [2].

In Cameroon, the region of Adamawa called the water tower of Cameroon is one of the ten regions with significant freshwater resources, including surface water (streams, rivers, lakes) and groundwater [3]. Despite this endowment, access to drinking water is rare in many rural and periurban areas of the region and especially in the area of Méiganga. So, the groundwater appears as the main source of water for the population, especially in the context of climate change. Therefore, a comprehensive understanding of the water system groundwater is necessary for the sustainable development of this key resource, with a particular focus on the rural areas of the Méiganga area. The main objective of the present work is therefore to contribute to a better supply of drinking water in the area of Méiganga and its surroundings. More specifically, we are studying the influence of lithology on the quality and flow of groundwater by mapping the geological structures, 
hydrogeological features, and delineating areas recharge and discharge of groundwater for the exploration and development of underground resources in the surrounding villages.

\section{Location and Hydrogeological Background of the Study Area}

Méiganga is the main town of the Mbéré department, located in the Adamawa region of Cameroon. This study area, with about $1129 \mathrm{~km}^{2}$ of surface area, is situated between longitudes $14^{\circ} 00^{\prime}$ and $14^{\circ} 25^{\prime}$ and latitudes $06^{\circ} 28^{\prime}$ and $06^{\circ} 43^{\prime}$ (Figure 2), with altitudes ranging from 920 to $1200 \mathrm{~m} \mathrm{[3].} \mathrm{The} \mathrm{climate} \mathrm{is}$ subhumid, with a mean annual rainfall of $1662 \mathrm{~mm}$ [4]. The mean annual temperature is $22.6^{\circ} \mathrm{C}$ [4].

From a hydrographic point of view, the work of Olivry [5] gives some information on the hydrographic basin of the northern part of Cameroon. The Méiganga area belongs to the Mbéré hydrographic basin which is located in the Mbéré fault trough. The main river which is the Mbéré $(250 \mathrm{~km}$ total length) has a SW-NE general trend. It takes its source in the north of Méiganga at $1080 \mathrm{~m}$ altitude. The hydrographic network is composed of temporary and perennial streams with a dendritic network in the study area.

In the Mbéré department, groundwater exists mainly in crystalline (metamorphic/plutonic), volcanic, and sedimentary terrains as is shown in Figure 1 [6]. The hydrogeology of that northern part of Cameroon is the least studied and in general poorly known, although the works of Betah [7] and Djeuda Tchapnga [8] revealed two main aquifers: a top, shallow aquifer and a deep aquifer. The thick, weathered lateritic blanket and the highly altered and fractured rocks form the top aquifer. The thickness of this aquifer ranges from 8 to 20 $\mathrm{m}$. The deep aquifer is composed of low permeability fractured rocks. The lithology in both aquifers is either migmatitic, gneissic, quartzitic, or schistose. The top aquifer is the most widely exploited by the rural communities.

\section{Geological and Tectonical Setting}

Several works have been made in the Méiganga area and its surroundings for the geological knowledge of the area [5, 913]. These studies revealed that the geological formations of the Méiganga area and its environs are part of the central Panafrican belt of Cameroon, which is denominated has the Adamawa Yadé domain (AYD) (Figure 2). It is underlain by syntectonic, late-tectonic, and posttectonic granitoids $[9,10]$ which intrude in older metamorphic rocks. The granitoids present in the study area include biotite-muscovite granite and pyroxene amphibole-biotite granite $[12,13]$. The metamorphic host rocks consist of $2.1 \mathrm{Ga}$ metasediments (metamorphized conglomerates and clay sandstones) and orthogneisses, which were reworked during the Panafrican orogeny [11]. The metamorphic rocks that are found in the Méiganga area and its surroundings include pyroxene amphibole gneiss, amphibole-biotite gneiss and banded amphibolite.

In a tectonic point of view the Méiganga area and its surroundings are characterized by four major deformational

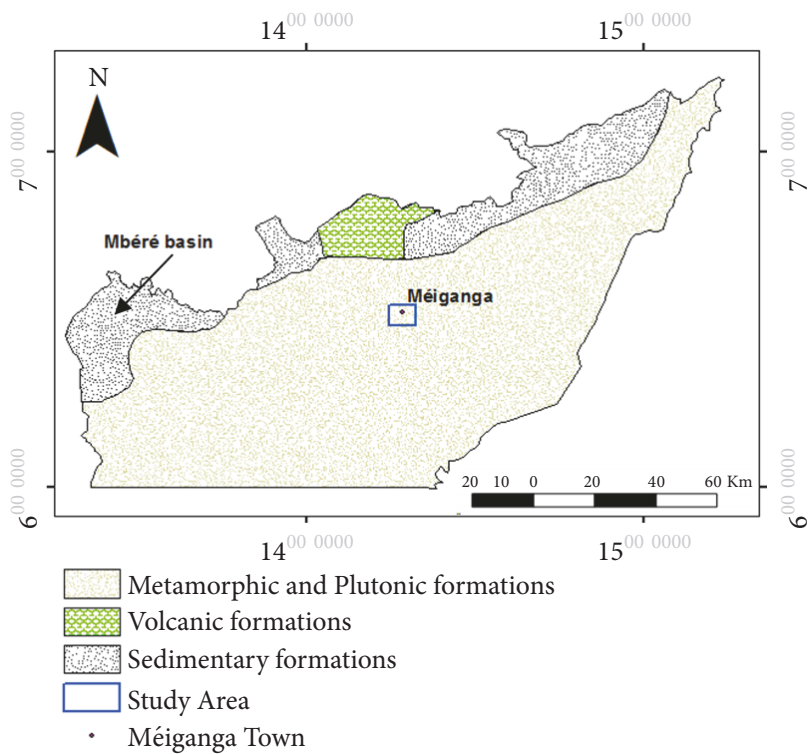

FIGURE 1: Main saturated geological formations in the Mbéré department modified from [6].

phases [15]. The first deformational phase D1 has put in place the S1 foliation subhorizontal and is present only in the gneisses and amphibolites. The deformational phase D2, shearing, is recorded in the gneisses and the metadiorite is put in place the schistosity S2. The dips of S2 are between $30^{\circ}$ and $90^{\circ}$ toward NW to N or S to SE (Figure 3). The C2 shear planes that strike direction are NNW-SSE indicating sinistral sense of shear in the area. The L2 lineation is characterized by stretched quartz or quartzofeldspathic aggregates and the alignment of amphibole and biotite that plunges up to $40^{\circ}$ to the NE or SW. The third deformational phase D3 is present in the granites especially in the pyroxene-granite, the metadiorite, and the gneisses. In the granites, it is represented by S3 (up to $90^{\circ} \mathrm{dip}$ ) and L3 lineation (up to $78^{\circ}$ plunge) acquired during syntectonic emplacement of the magmatic body. S3 is marked by preferred orientation of biotite and amphibole while L3 is characterized by the alignment of feldspar and hornblende and the stretching of quartz. In the metadiorite and the gneisses, D3 is represented by S3 as well as F3 folds. S3 is observed in the folded dike of the pyroxene-granite. These regional folds are related to NW-SE to NNW-SSE shortening. The last deformational phase D4 is brittle. This phase produces joints and faults in outcrop scale in all lithologies. The faults (trending N110E) show oblique dextralnormal displacement. D4 is due to NE-SW extension [12].

\section{Geophysical Methods}

4.1. Electrical Resistivity Tomography (ERT) Method. Electrical resistivity tomography (ERT) method belongs to the geoelectrical family of the geophysical methods and it is based on the application of electric current into analyzed bedrock and measurement of the intensity of electric resistivity to its conduit $[16,17]$. The technique was developed for the investigation of areas of complex geology where the use of resistivity 


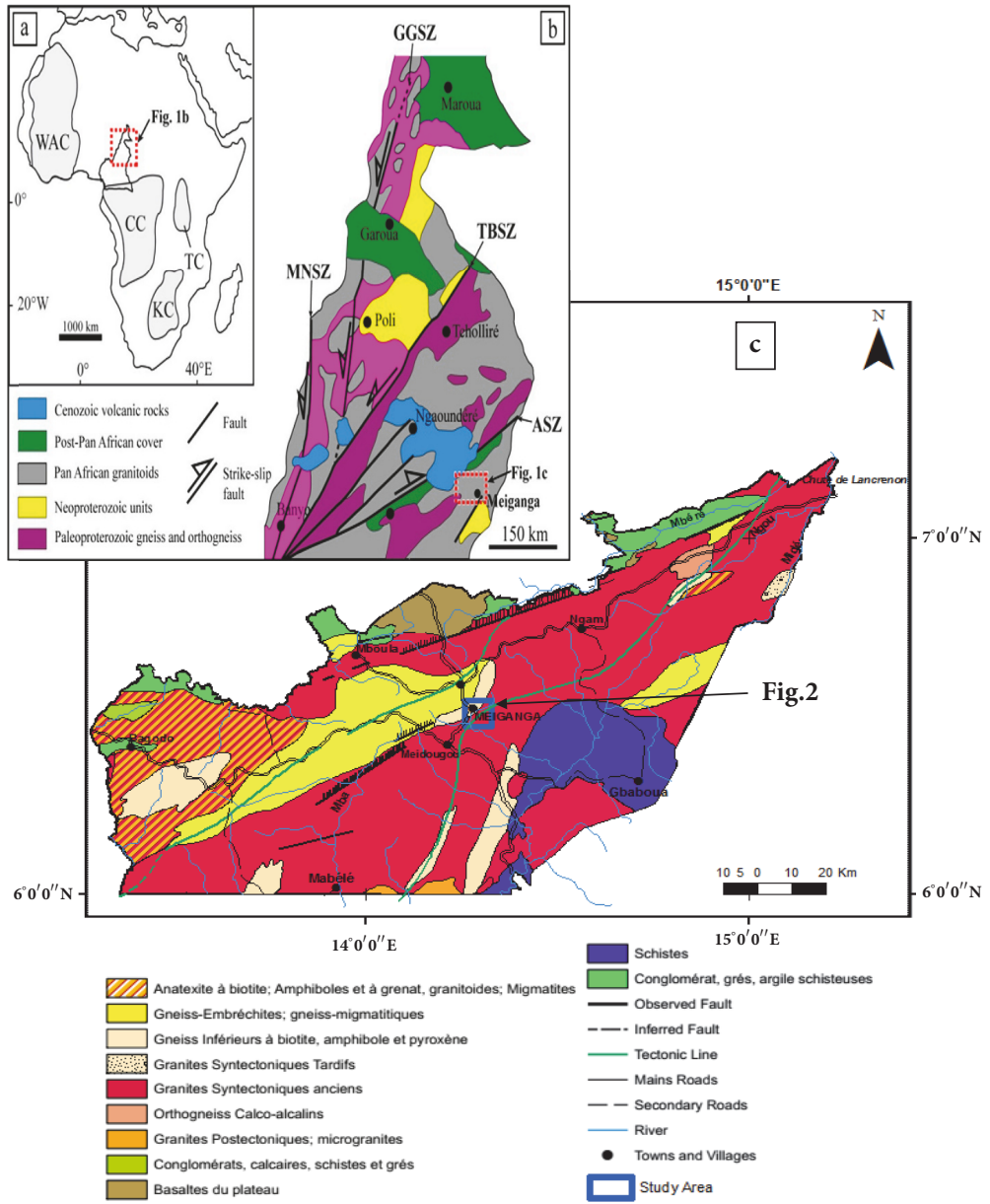

FIgURE 2: (a) Location of Cameroon in Africa, WAC: West African Craton; CC: Congo Craton; TC: Tanzanian Craton; KC: Kalahari Craton. (b) Geological sketch map of northern part of Cameroon showing from the major lithotectonic domains ([9, 14]; Baise, 1995); MNZ: Mayo Nolti shear zone; TBSZ: Tcholiré-Banyo shear zone; ASZ: Adamoua shear zone. (c) Geological map of the Mbéré department, redrawn (source: Department of Mines and Geology, 1979).

sounding and other techniques is unsuitable [18, 19]. It has an added attraction of providing a relatively low cost and noninvasive and rapid means of generating $2 \mathrm{D}$ models of the geoelectrical properties of the subsurface $[20,21]$. ERT is widely used in groundwater prospecting and other geoscientific studies [18, 22-25]. The concept involves applying multicore cables which contain as many individual wires as the number of electrodes, with one take-out every $5 \mathrm{~m}, 10 \mathrm{~m}$, and a set of 24, 48, 72, and 96 electrode layouts [26]. Two-end electrodes emit electric current whose run in the bedrock has character of a part of arc of a circle. The other two electrodes, localized between the emitted electrodes, measure the bedrock electric resistivity in a certain point under the surface $[27,28]$. The apparent resistivity $\rho_{a}$ in Ohm.m $(\Omega . \mathrm{m})$ is then computed from Ohm's law [29]:

$$
\begin{aligned}
\rho_{a}=k \frac{\Delta V}{I} & \left\{\begin{array}{l}
k: \text { geometric constant } \\
\Delta V: \text { measured potential difference } \\
I: \text { electric current }
\end{array}\right.
\end{aligned}
$$

The use of multielectrode/multichannel systems for data acquisition in geoelectrical resistivity surveys has led to a dramatic increase in field productivity as well as increased quality and reliability of subsurface resistivity information obtained [30].

4.2. The Self-Potential Method. The self-potential (SP) method sometimes called spontaneous potentials is a passive geophysical method based on the natural occurrence of electrical fields on the Earth's surface generated mainly by electrochemical, electrokinetic, and thermoelectric sources. Combined with other geophysical methods, SP surveys are especially useful for localizing and quantifying groundwater flows and pollutant plume spreading and estimating pertinent hydraulic properties of aquifers (water table, hydraulic conductivity). The theoretical basis of the streaming potential was first worked out by Helmholtz [31]. He proposed that streaming potentials are present when conduction current balances the convection current caused by the preferential transport of positive ions. As the fluid moves under a pressure difference, $\Delta \mathrm{P}$, it drags positive charge with it producing the 


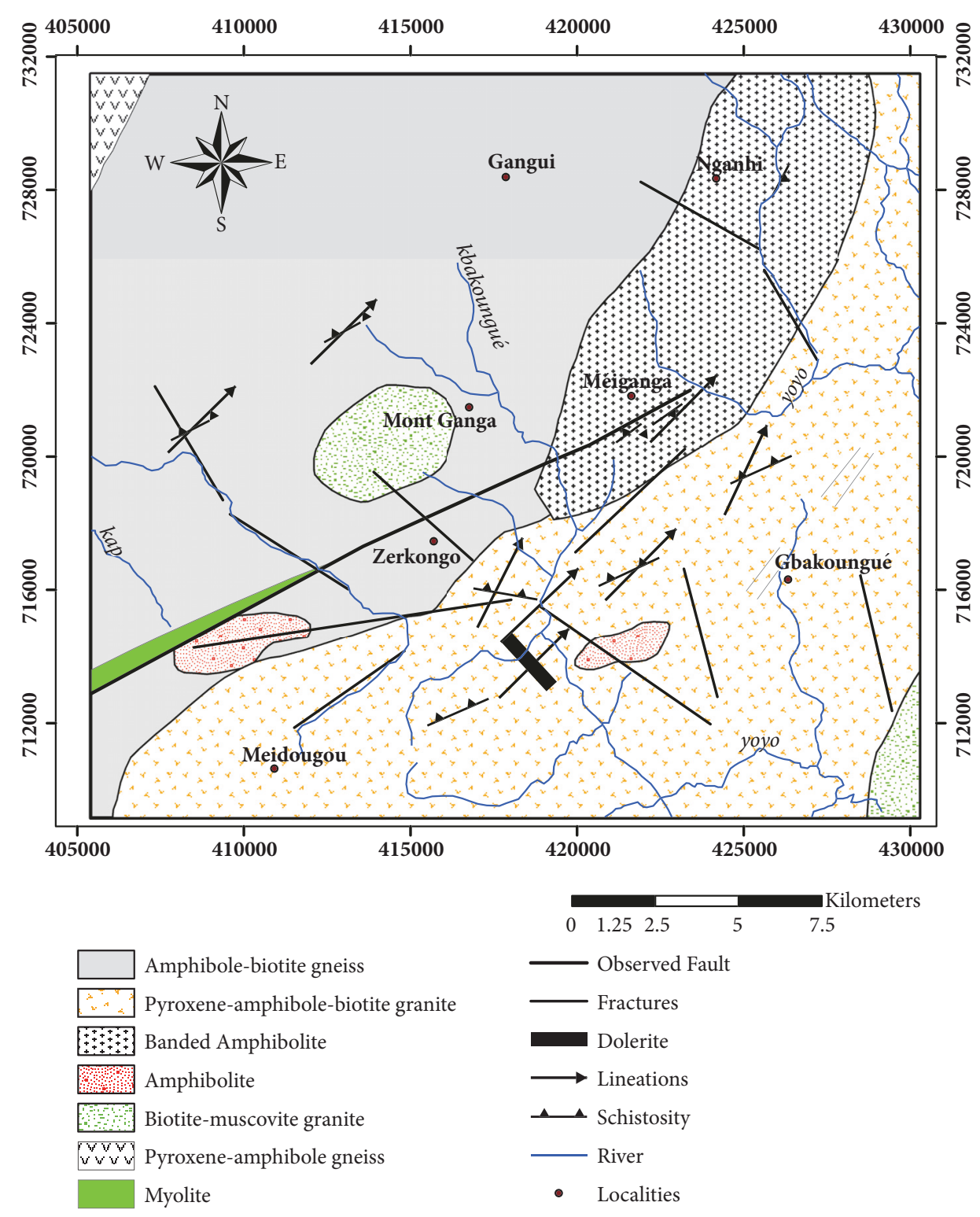

FIGURE 3: Geology and structural map of Méiganga area modified from [15].

convection current. The conduction current is simply Ohm's law equilibrium balancing current. This is leading to the Helmholtz-Smoluchowski equation [32]

$$
\Delta V=\frac{\zeta k}{\eta \sigma_{w}} \Delta P
$$

$$
\text { where }\left\{\begin{array}{l}
\Delta V: \text { streaming potential } \\
k: \text { Dielectric constant of the fluid } \\
\zeta: \text { Potential between }+ \text { and }- \text { layers } \\
\sigma_{w}: \text { Conductivity of the fluid } \\
\Delta P: \text { Difference of pressure } \\
\eta: \text { Viscosity of the fluid }
\end{array}\right.
$$

4.3. Data Acquisition. Concerning the geophysical survey, field resistivity data were obtained along eight imaging lines (Figure 3) using Schlumberger configuration and a maximum of sixteen levels was attained for each of the traverse. The Syscal Junior Switch 72, equipment manufactured by Iris Instruments, France was used for the measurements. An electrode spacing of $5 \mathrm{~m}$ was chosen for a maximum depth of investigation of $33.4 \mathrm{~m}$. These profiles were chosen according to the major tectonic accident direction in the region $\left(\mathrm{N} 70^{\circ} \mathrm{E}\right)$ given by the residual gravity map [33], which is also the major direction of the Adamawa regional structure. Adjusting the mode to SP, data was acquired linearly along the profiles. A laptop microcomputer together with an electrode-switching unit is used to automatically select the relevant four electrodes for each measurement. Apparent resistivity measurements are recorded sequentially sweeping any quadripole (current and potential electrodes) within the multi electrode array. 
4.4. ERT Data Processing. The first operation on the data is done with the help of the Prosys II software. It consists of extracting the absurd values of the apparent resistivity $(0<\mathrm{Rho}<10000)$ and the $\mathrm{X}$ and $\mathrm{Y}$ corresponding positions. The file is then exported in Res2Dinv format.

A least-squares smoothness constrained inversion algorithm, RES2DINV version 3.71 of Loke and Dahlin [34], was used to estimate the true resistivity of subsurface geological formations and structure. In the $2 \mathrm{D}$ inversion of resistivity data, Dahlin and Loke [35] have found that, in areas with large resistivity contrasts, the Gauss-Newton least-squares inversion method leads to significant accurate results more than the quasi-Newton method [36]. The quality of the inversion result is related to the quality of the field resistivity data and is reflected in terms of RMS error on the inverted resistivity models and is obtained by calculating the residuals between the measured and the calculated value of the apparent resistivity [37]. The inversion is stopped once the difference of the root mean square (RMS) error between the current and previous iterations is $<5 \%$. The inverted data produce the $2 \mathrm{D}$ resistivity distribution map, which can then be used for extracting information about the contact between sediments and bedrock. The inversion values are shown in [38].

\section{Results}

5.1. Geoelectrical Sections. Looking over the whole results obtained, they reveal significant variations of electrical resistivity of the substratum testifying its heterogeneity. The depth of investigation reached was about $34.2 \mathrm{~m}$ on each profile. This depth corresponds to the maximum cable length $(\mathrm{AB}=$ $180 \mathrm{~m}$ ) according to the XL position along a profile.

Pseudo-Section 1. The 2D inverted section (Figure 4) clearly shows a layer of resistive materials as the topsoil with high resistivity ranging from $\sim 3000$ to $13090 \mathrm{Ohm} . \mathrm{m}$ and a decreasing thickness from about $12.4 \mathrm{~m}$ at the beginning to 3.8 $\mathrm{m}$ toward the center. Its represents the outcropping gneiss. At a depth of $19.8 \mathrm{~m}$ and a lateral distance of 70 to $90 \mathrm{~m}$ appears a dome-like structure with higher resistivity values which is also an indication of basement high. Below the topsoil unit appears a weathered layer with resistivity ranging from 847 to $3000 \mathrm{Ohm}$.m with an increasing thickness from about $11.85 \mathrm{~m}$ to $20.4 \mathrm{~m}$ toward the center. Between electrodes position 125 to $150 \mathrm{~m}$ another weathered layer is revealed at $6.38 \mathrm{~m}$ depth. Regarding the lower part of this inverted section two conducting zones can be observed between electrodes position 40 to $60 \mathrm{~m}$ and 95 to $120 \mathrm{~m}$ at a depth of 19.8 and $33.8 \mathrm{~m}$, respectively. They constitute the weathered and saturated basement with resistivity ranging from $\sim 235$ to 500 $\mathrm{Ohm} . \mathrm{m}$ indicating a potential groundwater target. These low resistivity zones surrounded by high resistivity and impermeable rooftops suggest a captive aquifer zone. Two supposed fractures have been identified at depths of $12.4 \mathrm{~m}$ below electrodes position 65 to $75 \mathrm{~m}$ and 95 to $105 \mathrm{~m}$ with SW to NE general trend (red dashed line).

Pseudo-Section 2. It is located near the Institute of Geology and Mining Engineering campus with a NW to SE trend.
The inverted section (Figure 5) clearly shows three layers formations. The first continuous surface layer with high resistivity ranging from $\sim 2260$ to $16400 \mathrm{Ohm}$.m represents the top soil. It is composed of lateritic breastplate with approximately thickness ranging from $\sim 5$ to $12 \mathrm{~m}$. Below this unit a mean resistivity formation is observed with resistivity ranging from 500 to $2200 \mathrm{Ohm}$.m. It appears at a depth of $\sim 15 \mathrm{~m}$, among $10 \leq \mathrm{XL} \leq 160$ with a thickness ranging from about 10 to 15 $\mathrm{m}$. This same formation is relocated between $\mathrm{XL}=50 \mathrm{~m}$ and $\mathrm{XL}=60 \mathrm{~m}$ to form substratum at depth. It is associated with prominent weathered and highly weathered gneiss. The third layer appears as conducting with resistivity of the order of 70 to $470 \mathrm{Ohm} . \mathrm{m}$ and an average thickness of about $25 \mathrm{~m}$. The resistivity modeled data lying below 40 to $120 \mathrm{~m}$ is inferred as the prospect and potential groundwater zone (black line on the inverted section). Due to the fact that this zone is relocated between semi-impermeable rooftops the aquifer zone is captive.

Pseudo-Section 3. It is located near a public school in SWNE direction. The inverted modeled (Figure 6) clearly shows a thick layer of resistive materials as the topsoil with resistivity ranging from $\sim 850$ to $8370 \mathrm{Ohm} . \mathrm{m}$ and approximate thickness ranging from $\sim 12.4$ to $16 \mathrm{~m}$. This highly resistive formation could be associated with the lateritic formation present in the area. Below this unit appears a mean resistivity formation showing smooth variations of resistivity which ranges from 439 to $1230 \mathrm{Ohm}$.m with an increasing thickness from $3.5 \mathrm{~m}$ to $12 \mathrm{~m}$ toward the southeastern part of the section. It represents the fresh and weathered gneiss. The third layer formation appears conducting with very low resistivity ranging from 70.8 to $350 \mathrm{Ohm} . \mathrm{m}$. This layer is relocated between electrodes positions 40 to $50 \mathrm{~m}$ at a depth of $19.8 \mathrm{~m}$ indicating a potential groundwater target. This very low resistivity zone surrounded by high resistivity and impermeable rooftops suggests a captive aquifer zone. A supposed fracture has been observed at a depth of $13 \mathrm{~m}$ below the electrode position of $55 \mathrm{~m}$ (red dashed line) with quasivertical trend.

Pseudo-Section 4. The inverted resistivity model at NgoaEkélé site (Figure 7) is showing a prominent lateral heterogeneity from NWW to SEE direction. It is located near a primary school. The near-surface layer is characterized by lateritic formations with resistivity ranging from $\sim 600$ to $4500 \mathrm{Ohm} . \mathrm{m}$, and this layer is growing thicker toward the center between electrodes position 55 to $75 \mathrm{~m}$ and reached a depth of $12 \mathrm{~m}$. A comparatively low resistivity $\sim 150$ to 580 Ohm.m zone revealed up to 3.8 to $15 \mathrm{~m}$ depth laying the whole profile and is recovered as anomalies formations under mean resistivity formations indicating saturated fractured gneissic arena underlain by unfractured gneiss. This low resistivity zone surrounded by high resistivity suggests a prospect groundwater target (marked by black line). Below $19.8 \mathrm{~m}$ depth, appears a gneissic basement with resistivity ranging of 5180 to $27490 \mathrm{Ohm} . \mathrm{m}$ all along the section showing no major sign of groundwater resource at a deeper level. A supposed fracture has been observed (red dashed line) at depth of $12 \mathrm{~m}$ below electrode position of $120 \mathrm{~m}$ with a NW to SE direction. 
NW Model resistivity with topography

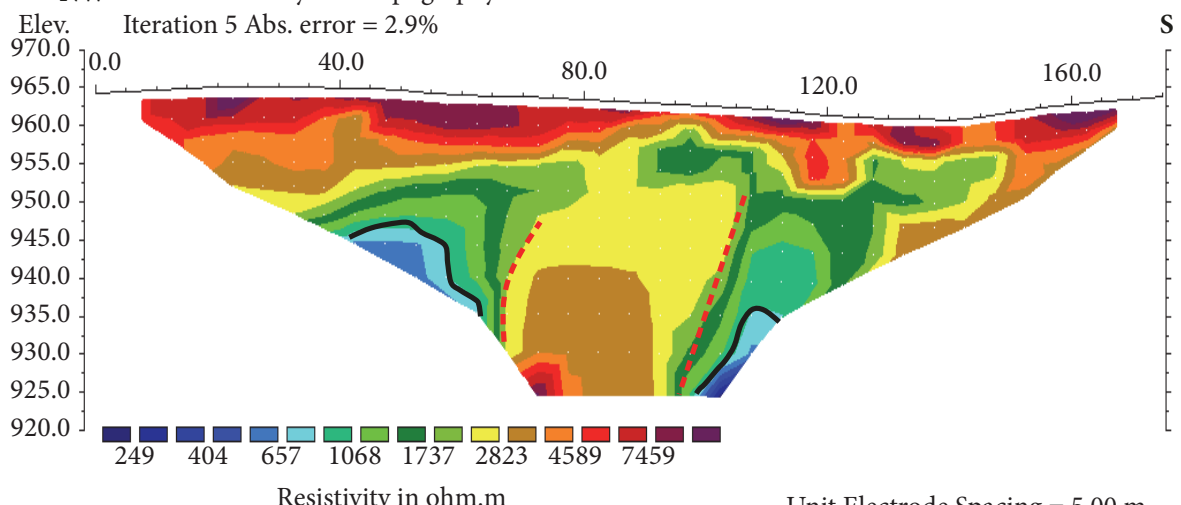

Resistivity in ohm.m

Unit Electrode Spacing $=5.00 \mathrm{~m}$.

\section{$\square$ Groundwater prospect zones \\ Probable fractures}

FIGURE 4: Inverse resistivity model along profile 1.

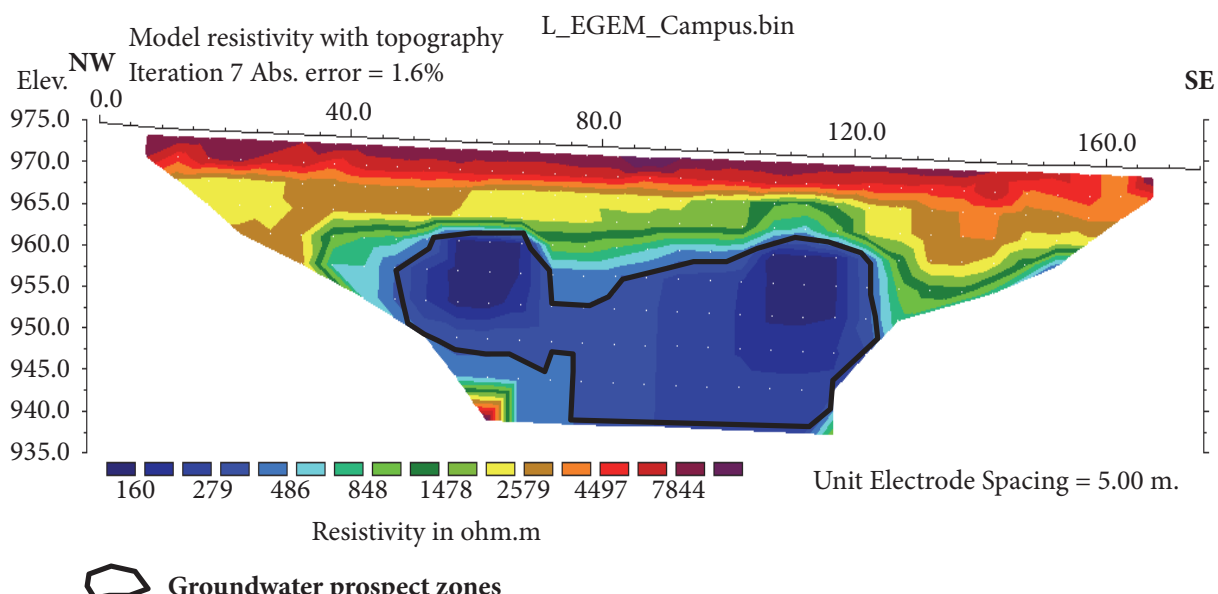

FIGURE 5: Inverse resistivity model along profile 2.

SW Model resistivity with topography

L_Ep_Sab.bin

Elev, Iteration 7 Abs. error $=1.1 \%$

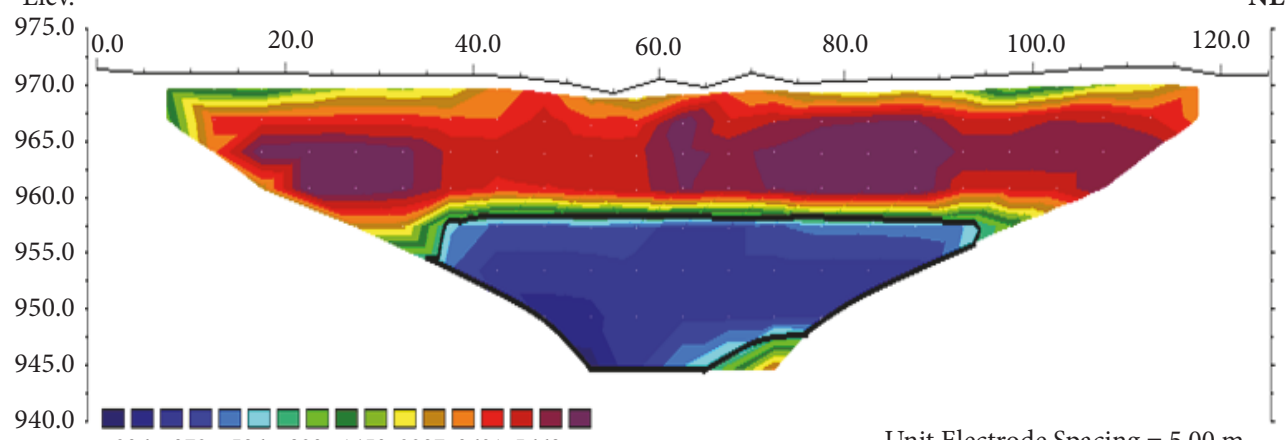

$\begin{array}{llllllll}236 & 372 & 586 & 923 & 1453 & 2287 & 3601 & 5669\end{array}$

Unit Electrode Spacing $=5.00 \mathrm{~m}$

Resistivity in ohm.m

Groundwater prospect zones

Figure 6: Inverse resistivity model along profile 3. 


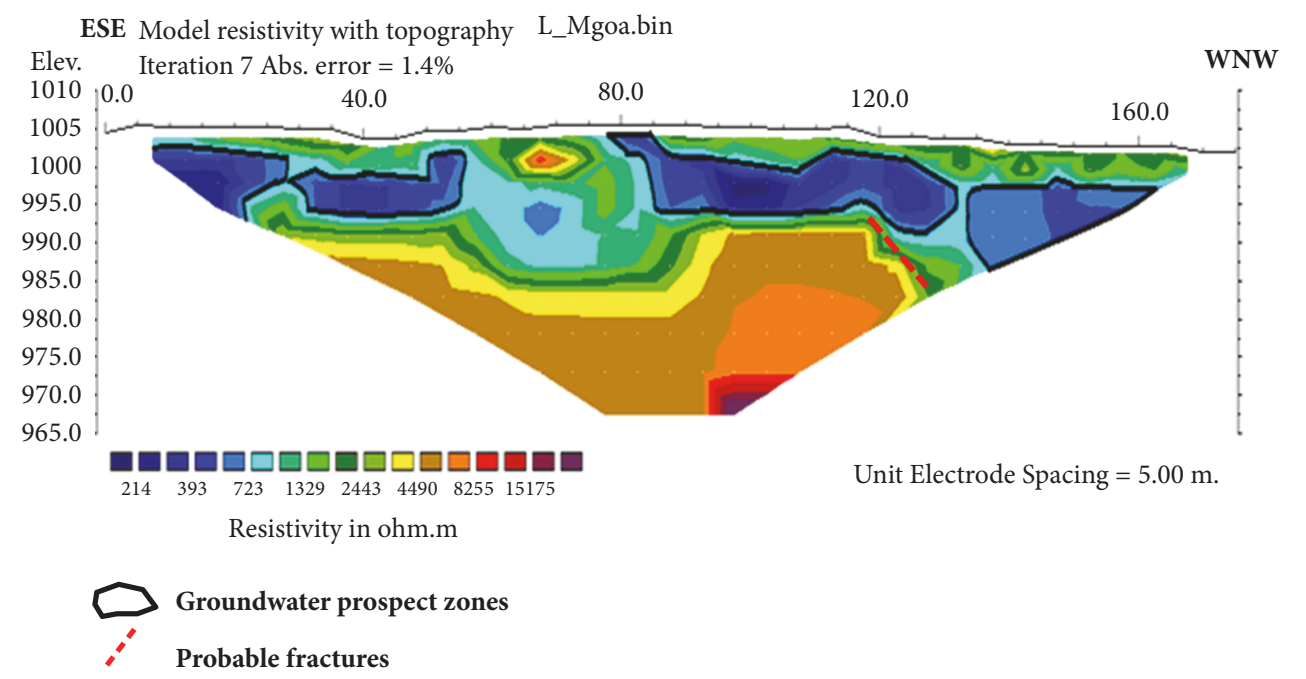

FIGURE 7: Inverse resistivity model along profile 4.

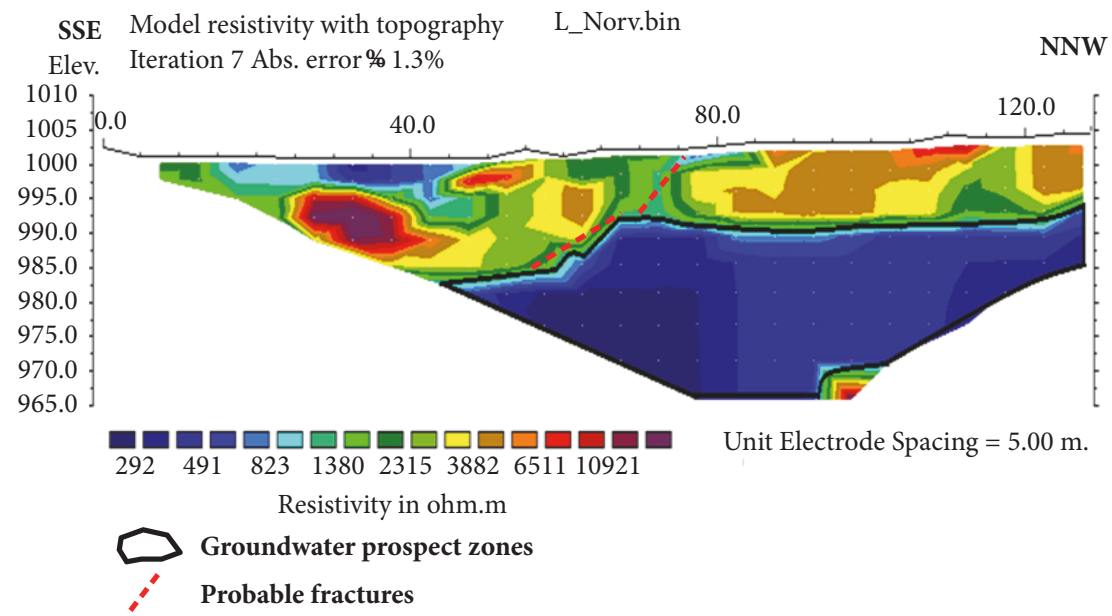

FIGURE 8: Inverse resistivity model along profile 5.

Pseudo-Section 5. This profile is located at Yelwa near a health center in approximately SE-NW direction. Near the eastern end of the profile (Figure 8), due to very bad data acquisition at specific electrode, positions had been removed from the raw data and are seen as data gap in the $2 \mathrm{D}$ resistivity model. The interpretation of the resistivity model shows that this site is very complex and heterogeneous in nature. The first layer formation is showing resistivity of the order of $\sim 660$ to $2800 \mathrm{Ohm}$.m relocated between electrode positions 5 to $30 \mathrm{~m}, 45$ to $55 \mathrm{~m}$, and 60 to $85 \mathrm{~m}$ and could be associated with the weathered/fractured gneiss arena. The second layer formation clearly shows high resistivity anomalies with a resistivity value of $\sim 3000-8560 \mathrm{Ohm}$.m. This highly resistive layer represents the lateritic formations. Toward the southern part of the profile another highly formation is observed and formed the gneissic basement. The third formation is a low resistivity layer and appears at a depth of $12.4 \mathrm{~m}$ with resistivity ranging from 150 to 490 Ohm.m. This layer is revealed at a lateral distance between 45 and $125 \mathrm{~m}$ indicating the prospect and potential groundwater zone. The aquifer zone is considered captive due to the fact that it is surrounded by impermeable rooftops. Two supposed fractures are identified with SW to NE general trend (red dash line).

Pseudo-Section 6. This section (Figure 9) shows a smooth variation of resistivity for the subsurface geological formations but with a large resistivity contrast varying from 3250 to $12890 \mathrm{Ohm}$.m. This highly resistive formation appears not only at the surface from the beginning of the profile to $\sim 100 \mathrm{~m}$ lateral distance with an average thickness of $\sim 12.4 \mathrm{~m}$ depth but at the right side of the profile from 145 to $155 \mathrm{~m}$ and also at depth to form the substratum. Given geology and field observations, this layer is made of lateritic breastplate. The second layer represents the first constituent formation which is made of fresh and weather gneiss with resistivity ranging from $\sim 930$ to $3000 \mathrm{Ohm} . \mathrm{m}$ and it is growing thicker in the right direction. The third layer formation appears as conducting with a resistivity ranging from $\sim 350$ to $850 \mathrm{Ohm} . \mathrm{m}$ and lying between 20 and $105 \mathrm{~m}$ with average thickness of $\sim 15 \mathrm{~m}$ indicating water saturated 


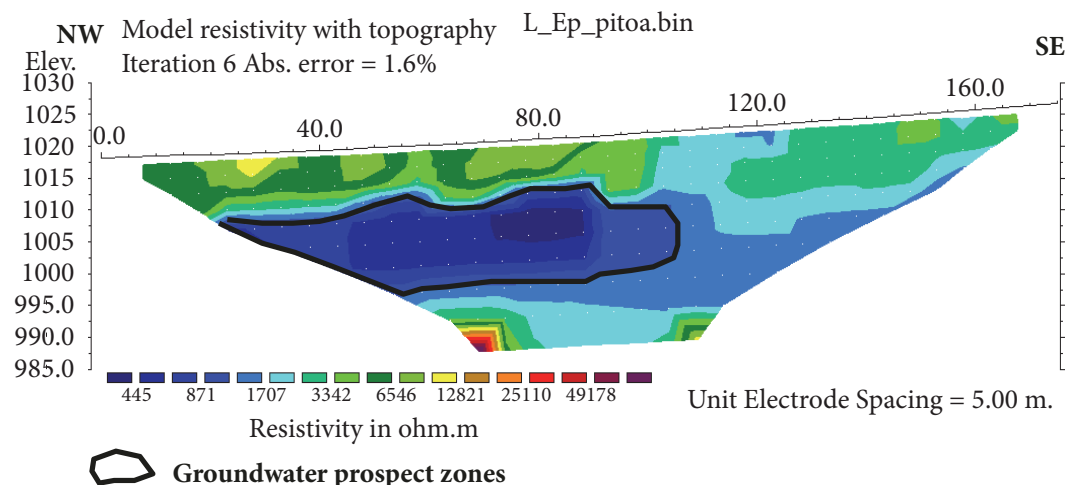

FIGURE 9: Inverse resistivity model along profile 6.

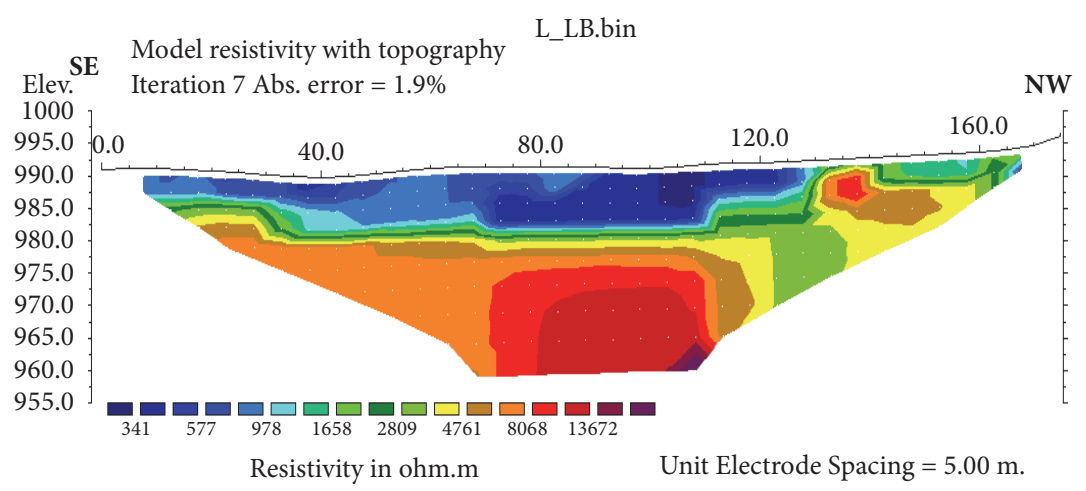

FIGURE 10: Inverse resistivity model along profile 7.

fractured gneiss. This low resistivity zone surrounded by high resistivity suggests a prospect and potential groundwater target (black line on the inverted section). This aquifer zone is captive because it is surrounded by impermeable rooftops.

Pseudo-Section 7. The 2D inverted subsurface resistivity model at Zandaba 1 is depicted in Figure 10. It is located near the government bilingual secondary school in SE-NW direction. The near-surface layer appears as conducting and is indicative of soil mixed with clay whose resistivity is $<250$ to $690 \mathrm{Ohm} . \mathrm{m}$ up to a depth of $9.38 \mathrm{~m}$ and at a lateral distance of $130 \mathrm{~m}$. Later, it is followed by an increase in resistivity with depth which represents weathered gneiss. Beyond 19.8 $\mathrm{m}$ depth, the high resistivity values indicate massive gneiss rock, which indicates no tectonic fracture showing no sign of prospect hydrogeological condition. Such area in hard rock is totally devoid of water.

Pseudo-Section 8. The ERT 2D inverted resistivity model at Zandaba 2 (Figure 11) depicts that the subsurface rock is highly heterogeneous and undulating in nature. It is located near the government technical secondary school in SE-NW direction and it is parallel to the one at Zandaba 1. The inverted section shows a thin layer of resistive material forming the top soil with a resistivity ranging from $\sim 3000$ to $26300 \mathrm{Ohm}$.m and lying from a lateral distance of $30 \mathrm{~m}$ to the end of the profile and it corresponds to a lateritic formation (breastplate and framework or carcass). This is followed by fresh and weathered gneissic arena showing resistivity of the order of 450 to $2820 \mathrm{Ohm} . \mathrm{m}$. This same formation appears between electrodes positions 45 to $105 \mathrm{~m}$ at $19.8 \mathrm{~m}$ depth. At a depth of $6.38 \mathrm{~m}$ a low resistivity zone is observed with resistivity of the order of 85 to $360 \mathrm{Ohm} . \mathrm{m}$ and laying the whole profile. This layer is inferred as the prospect and potential groundwater zone due to intense weathering/fracturing of rock strata is a significant repository for groundwater reserve, which can be exploited. Such aquifer is considered captive it because it is surrounded by high resistivity values and impermeable rooftops. The basement shows resistive structure made of gneiss with high resistivity values.

5.2. Self-Potential (SP) Profiles Analysis. The analysis of geoelectrical cross-section was able to withdraw six main depths (respectively, $6.56 \mathrm{~m}, 10.46 \mathrm{~m}, 14.33 \mathrm{~m}, 18.16 \mathrm{~m}, 21.83 \mathrm{~m}$, and $25.71 \mathrm{~m}$ ) from which the self-potential (SP) profiles plots for anomaly variations were constructed.

Figure 12 clearly shows good superimposition of SP curves and two deeper zones of water infiltration with negative peaks of -153.08 and $-126.34 \mathrm{mV}$ are delineated between 77.5 and 92.5 meters distance at $25.71 \mathrm{~m}$ depth while shallow infiltration zones are identified around 42.5 and 127.5 $\mathrm{m}$ distance at $14.33 \mathrm{~m}$ depth.

In profile 2 (Figure 13) positive peaks were observed at $22.5,42.5$, and 92.5 meters distance with magnitude value 


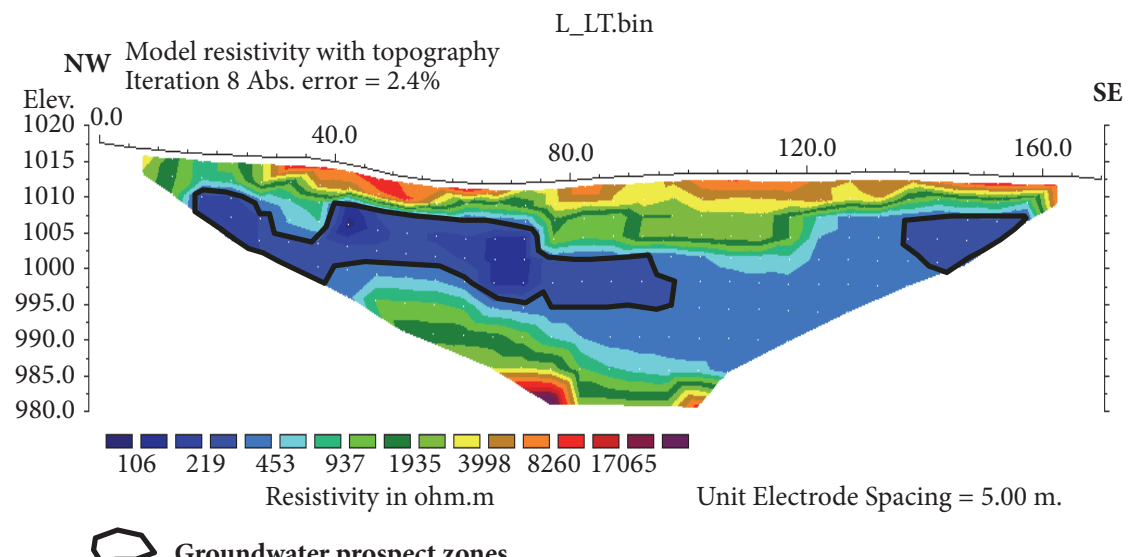

FIGURE 11: Inverse resistivity model along profile 8.

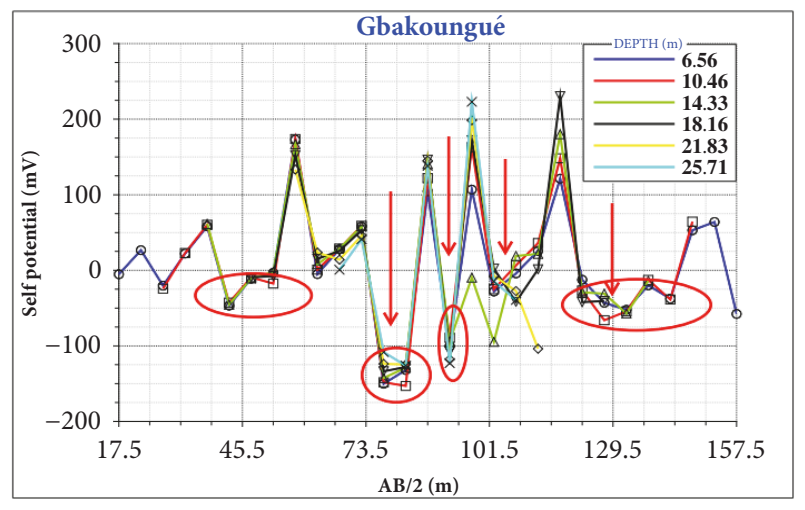

FIGURE 12: Plots of SP values against Half Electrodes Spacing (AB/2).

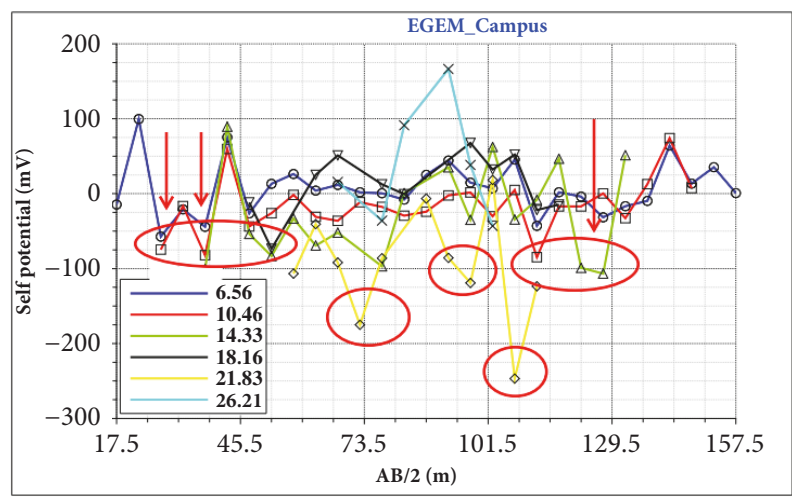

FIGURE 13: Plots of SP values against Half Electrodes Spacing (AB/2).

of $99.68 \mathrm{mV}, 89.35 \mathrm{mV}$, and $166.41 \mathrm{mV}$, respectively. Low SP anomalies are also observed and have been marked by red circle with peaks of $-100.81 \mathrm{mV},-106.77 \mathrm{mV},-119.17 \mathrm{mV},-246.74$ $\mathrm{mV}$, and $-123.61 \mathrm{mV}$. These low SP anomalies correspond to shallow zone of water infiltration (vertical red arrow lines) while at depth of $21.83 \mathrm{~m} \mathrm{SP}$ value shows only negative maxima and minima and could be associated with a deeper zone of infiltration.
Profile 3 (Figure 14) indicates a dominancy of positive $\mathrm{SP}$ peaks with value ranging from 80 to $120 \mathrm{mV}$. Here the superimposition of SP curves at $67.5 \mathrm{~m}$ distance makes this zone an infiltration zone and reaches $18.16 \mathrm{~m}$ depth.

In profile 4 (Figure 15) the SP profiles curves are scattered and clearly show dominance of positive peaks. At depths of 10.46 and $18.16 \mathrm{~m}$, SP value shows only negative maxima and minima and could be associated with shallow zone of infiltration (big red circle).

Figure 16 revealed high anomaly peaks at $62.5,112.5$, and 127.5 meters distance with amplitude values of $192.5,381.04$, and $338.56 \mathrm{mV}$ while low SP peaks appear at $67.5,102.5$, and 107.5 meters distance with magnitude values of -129.47 , -182.79 , and $-147.29 \mathrm{mV}$. Here the superimposition of the SP curves at these locations (low SP value) clearly shows that the water infiltration is deeper and reaches $25.71 \mathrm{~m}$ depth (red circle).

In profile 6 (Figure 17), one can observe that curves begin with short wavelength oscillation of SP values with small amplitude and end with large wavelength oscillation. Here only shallow zones of infiltration were delineated (marked by red circle).

On Figure 18, one can identify five zones of discontinuities (red circles) at 47.5, 72.5, 82.5, 127.5, and 137.5 meters distance where all the SP curves have the same concavity. These zones correspond to zone of water infiltration marked here by vertical red arrow lines.

On Figure 19, high positives peaks are observed between 82.5 and 102.5 meters distance with magnitude ranging from 266.17 to $352.47 \mathrm{mV}$ while negatives peaks appear at 62.5 , $92.5,102.5$, and 107.5 meters distance with values of -236.66 , $-224.75,-189.82$, and $-214.09 \mathrm{mV}$. Three deeper zones of water infiltration have been delineated (red circle) at 18.16 and 20.06 $\mathrm{m}$ depth.

\section{Hydrogeological Analysis}

From the hydrogeologic measurement across the study area, Figures 20, 21, and 22 have been constructed. These maps revealed areas of recharge and discharge across the study area. 


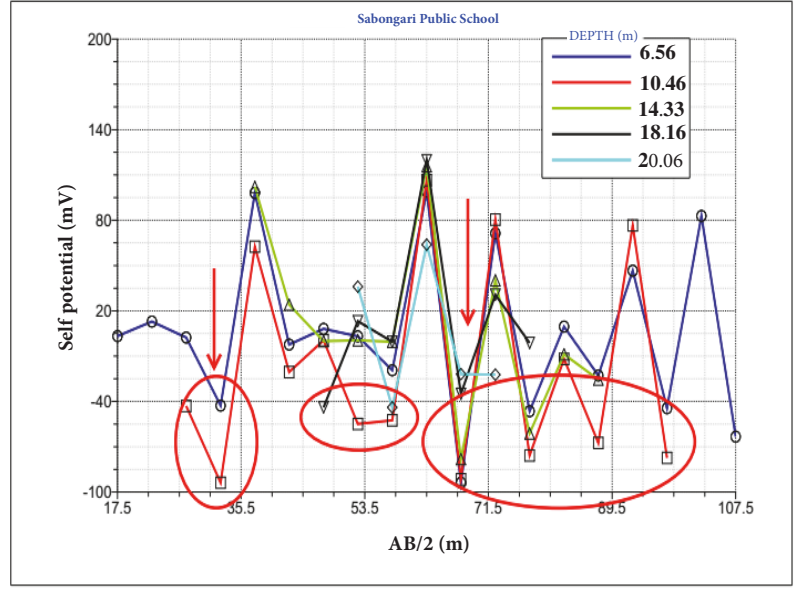

Figure 14: Plots of SP values against Half Electrodes Spacing (AB/2).

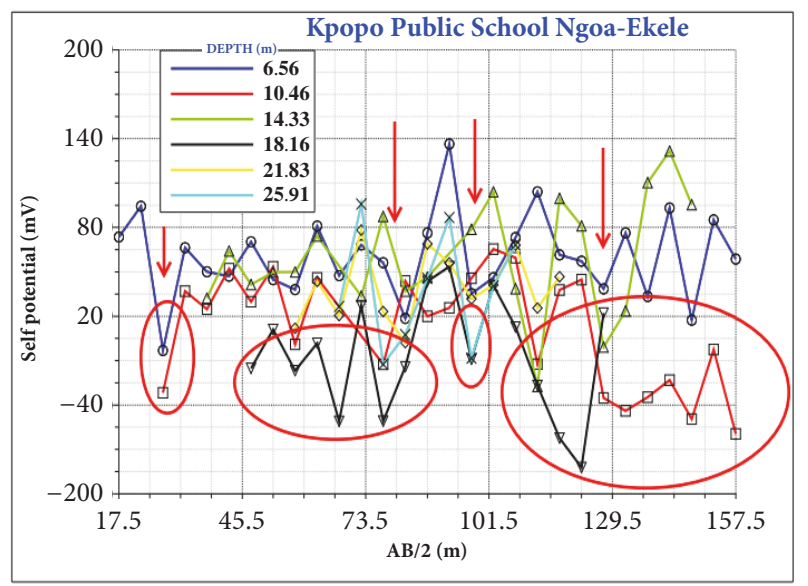

FIGURE 15: Plots of SP values against Half Electrodes Spacing (AB/2).

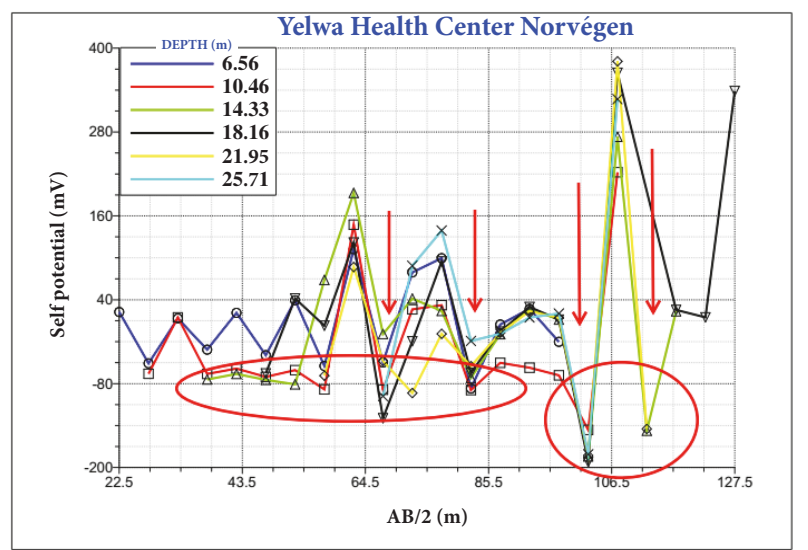

FIGURE 16: Plots of SP values against Half Electrodes Spacing (AB/2).

On Figure 21, one can observe that the static water elevation across the study area varies from 970 to $1025 \mathrm{~m}$ and the peaks observed correspond to zone of high piezometric level. The groundwater head map (Figure 20) shows that groundwater exists at greater depth within the southeastern part and a bit toward the northeastern part of the study area but it exists at

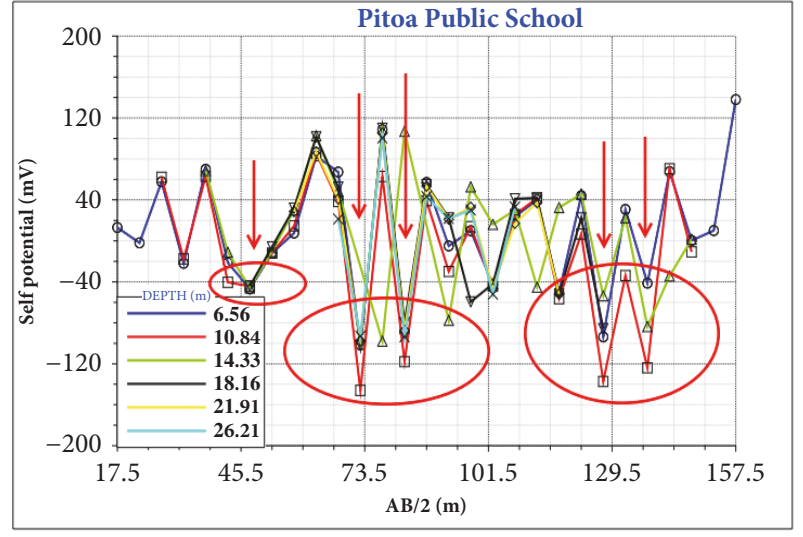

FIGURE 17: Plots of SP values against Half Electrodes Spacing (AB/2).

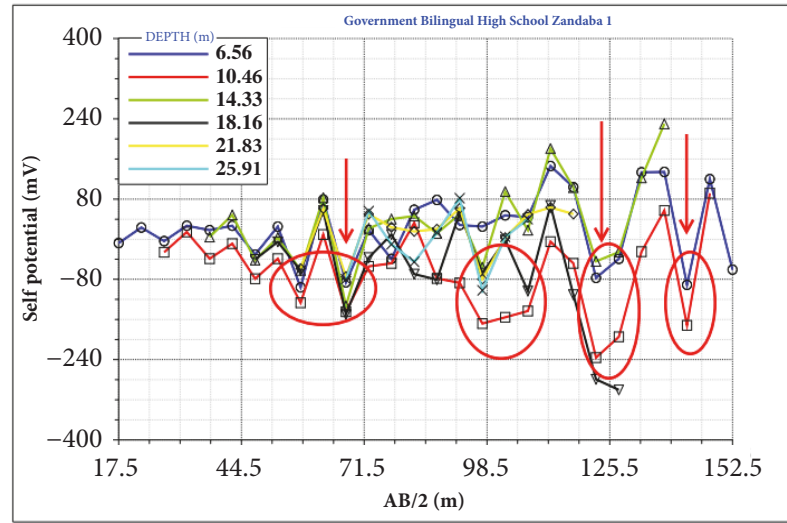

FIgURE 18: Plots of SP values against Half Electrodes Spacing $(\mathrm{AB} / 2)$.

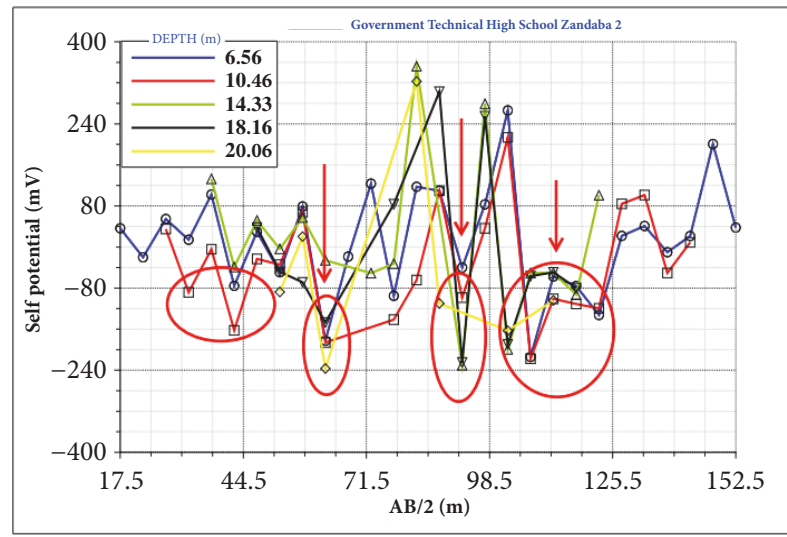

FIgURE 19: Plots of SP values against Half Electrodes Spacing $(\mathrm{AB} / 2)$.

shallow depth at the northern and parts of northwestern area. This may be due to relative lower ground surface elevation and near-surface outcropping of the bedrock. Groundwater flow direction is shown as vector grids (Figure 22), with arrows showing the flow pattern from higher elevation to lower elevation areas. It can be deduced that water recharges areas are located along northwestern, northeastern, and 


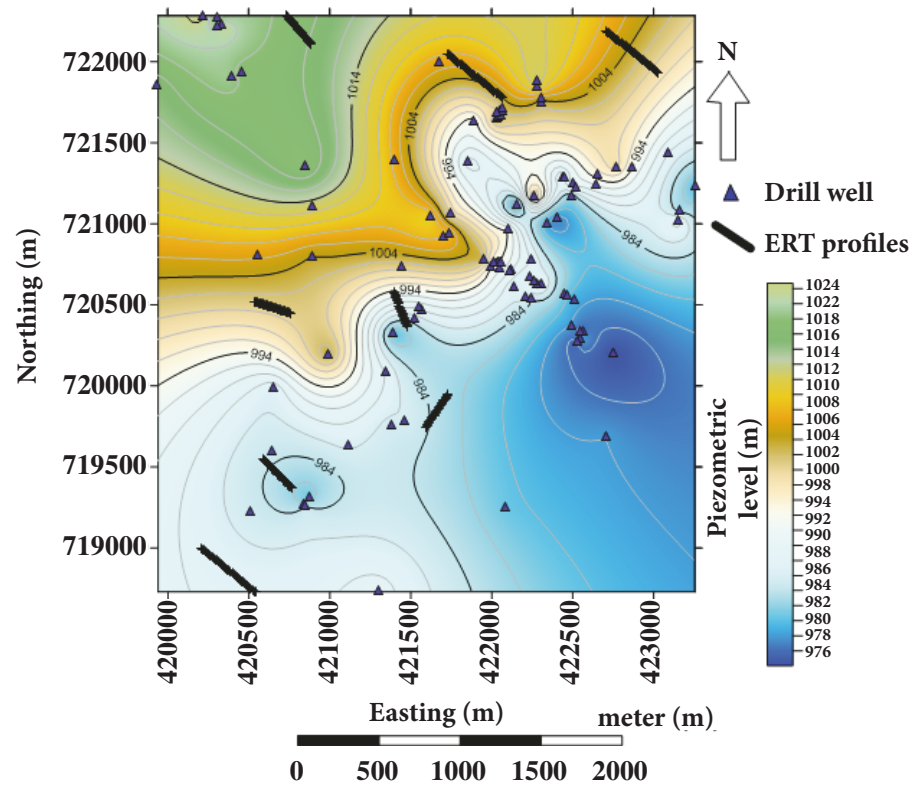

FIgURE 20: Groundwater head map of the study area.

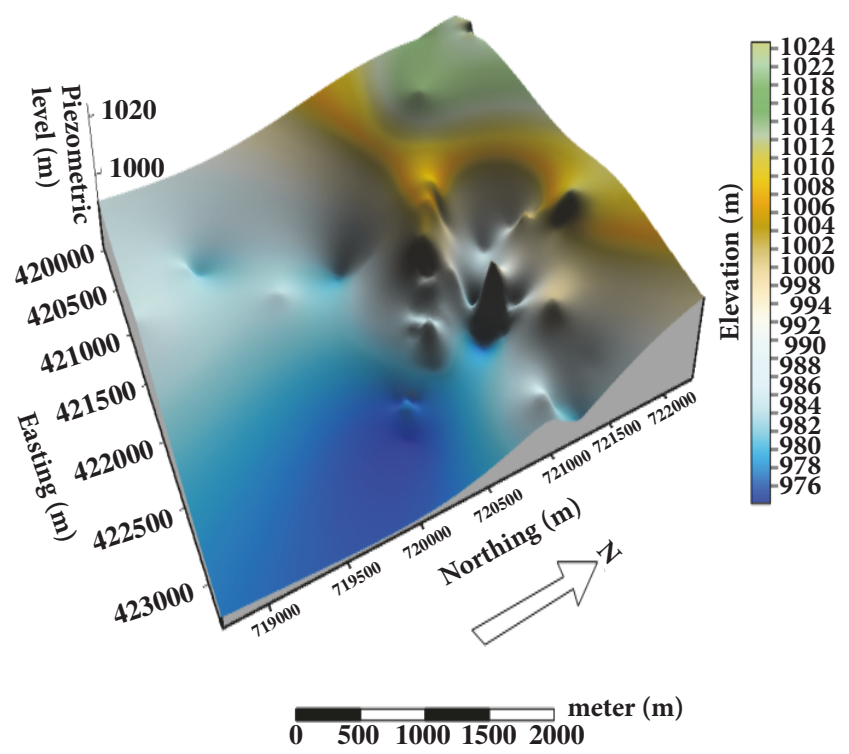

FIGURE 21: 3D piezometric model of the study area.

southwestern parts of the study area, while discharges areas are visibly situated at the central and southern parts of the of the study area. The discharge areas serving as groundwater collection center are good groundwater potential zones.

\section{Discussion of Results}

The analysis of the results from the geophysical survey enables us to identify three different geological formations. The formations encountered from the surface to the depth were various lateritic formations (lateritic soils, laterites) with high resistivity values (> 2000 Ohm.m), a gneissic weathered/fractured arena with low resistivity values $(<850$ Ohm.m) which represents the aquifer formation and the gneissic basement. The inverted resistivity models revealed weakness zones that can be interfered with potential and productive groundwater zones. On profiles 1, 2, 3, and 4 (Figures 4, 5, 6, and 7) these zones are located around 20 to 25 $m$ depth and are considered deeper groundwater zones while on profiles 5,6 , and 8 (Figures 8,9 , and 11) there are shallow depths at around 10 to $13 \mathrm{~m}$ located between two resistive formations. These two zones constitute the two main aquifers in the area as shown by Betah [9] and Djeuda Tchapnga et al. (1987). On profile 7 (Figure 10) the low resistivity observed is associated with the agricultural soil. From the SP profiles curves, shallow and deeper water infiltration zones were also highlighted in these various formations through the measurement and detection of negative peaks of SP. It emerges that these zones of negative SP anomalies are characteristic of draining basins and the greater the flow is, the greater the amplitude of the negative potentials increases. The comparison of these geophysical results reveals clear coherence between the SP negatives anomalies and the observed values of apparent electrical resistivity. On profile 1 (Figures 4 and 12), for example, one can easily notice that the negative, strong, and high anomalies peaks (-120 to $150 \mathrm{mV}$ ) of the spontaneous potential localized between 77.5 and $97.5 \mathrm{~m}$ correspond to the deeper conductive anomalies (around 350 Ohm.m) on the apparent electrical resistivity pseudo-section (marked by black contours), while on profile 2 (Figures 5 and 13) at depth of $21.83 \mathrm{~m}$ one can also see that SP value shows only negative maxima and minima and corresponds also to conductive anomalies on the apparent resistivity pseudo-section. The observation of negative SP anomalies and low resistivity values at the same locations can be explained by the presence of wet clays in the soil due to an overgone alteration of the gneiss in deep. 


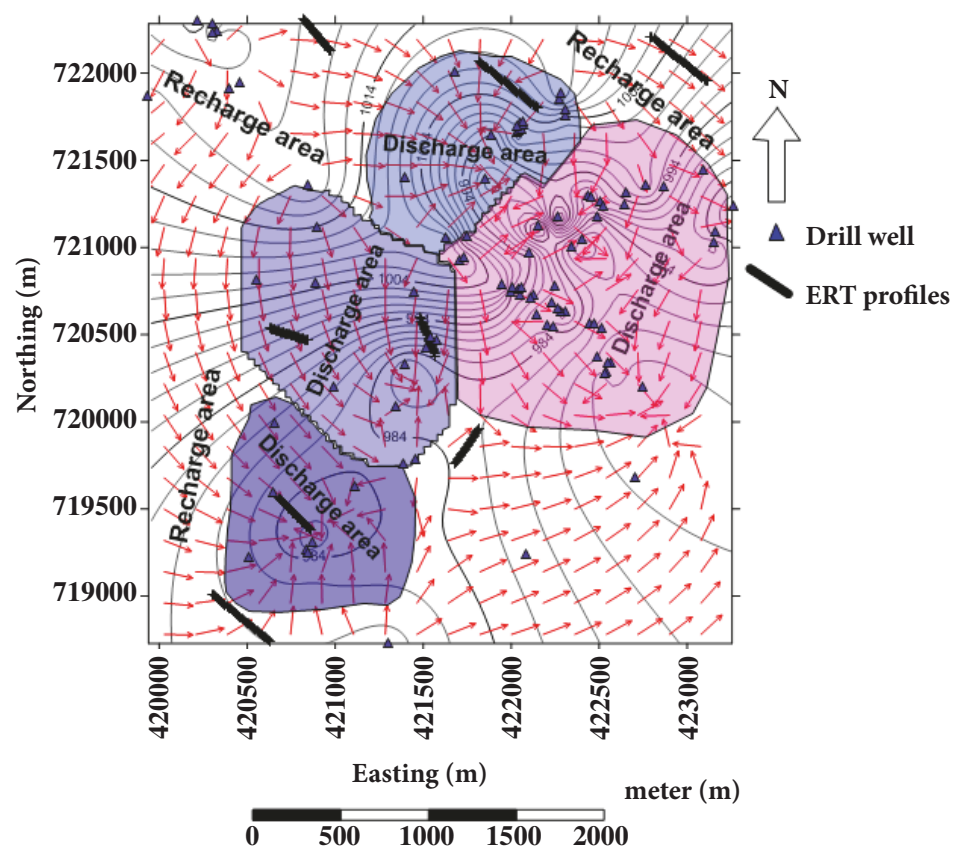

FIGURE 22: Groundwater vector map of the study area.

In addition the correlation of hydrogeological, geoelectrical pseudo-sections and SP results shows that groundwater will flow from the northern and parts of northwestern of the study area to the southern and southeastern sector. Superficial zones of recharge and discharge have been delineated (Figure 22).

Water recharges areas are located along northern, northwestern, and southwestern parts of the study area, while discharges areas are visibly situated at the central and southern parts of the of the study area (marked by blue and pink contours). This explains why many wells were drilled at the center-eastern part.

\section{Conclusion}

Electrical Resistivity Tomography can be considered as a suitable and powerful method for the subsurface geological setting and structure of the gneiss rocks and the self-potential techniques give significant results in describing the main pattern of the subsurface fluid flows and the status of the groundwater scenario in the study area. Hence the true resistivity models generated using inversion in conjunction with the measured apparent resistivity dataset had been helpful in resolving geological formations, structures, basement topography, depth to bedrock, and the potential groundwater resource in the present geological setting. The analysis of SP profiles curves had helped delineate deeper negative, strong, and highly localized anomalies which correspond to the conductive anomalies. In the present study, it is concluded that shallow $(<13 \mathrm{~m})$ groundwater zones are at high elevation (at Pitoa, Zandaba 1 and Zandaba 2) and best prospect and productive groundwater zones lying between 20 and $25 \mathrm{~m}$ depth are at low elevation (Gbakoungué, Sabongari, Yelwa, Ngoa-Ekélé, and Ngassiri) which are the deeper groundwater zones from where boring and drilling wells could be developped for the groundwater exploitation. In addition groundwater head map alongside groundwater vector map shows that groundwater flow is directed from the flanks (recharge area) to the central part of the study area (discharge area) demonstrating the significance of the geoelectric pseudosections especially in areas where there is little or no boring information.

For future works, the use of borehole would help better identify the geological formations with the different characteristics. Also the development of monitoring system enabling us to measure the time-dependent changes of the self-potential values along selected profiles will disclose the way for the time-lapse analysis of the self-potential profiles. These new techniques could help us better understand the time dynamics of the geoelectrical parameters in connection with meteorological conditions and identify zones of likely high water content.

\section{Data Availability}

The data used to support the findings of this study are available from the corresponding author upon request.

\section{Conflicts of Interest}

The authors declare that there are no conflicts of interest regarding the publication of this paper.

\section{Acknowledgments}

The authors are grateful to Professor NGOUNOUNO Ismaila, Head of School of Geology and Mining Engineering, 
University of Ngaoundéré, for providing the Syscal Junior Switch 72 to collect the datasets and processing software used in this study.

\section{References}

[1] A. Sirhan, M. Hamidi, and P. Andrieux, "Electrical resistivity tomography, an assessment tool for water resource: case study of Al-Aroub Basin, West Bank, Palestine," Asian Journal of Earth Sciences, vol. 4, no. 1, pp. 38-45, 2011.

[2] O. Anomohanran, "Hydrogeophysical and hydrogeological investigations of groundwater resources in Delta Central, Nigeria," Journal of Taibah University for Science, vol. 9, no. 1, pp. 5768, 2015.

[3] M. G. Dedzo, D. Tsozué, M. E. Mimba, F. Teddy, R. M. Nembungwe, and S. Linida, "Importance of rocks and their weathering products on groundwater quality in central-east Cameroon," Hydrology, vol. 4, no. 2, p. 23, 2017.

[4] J. B. Suchel, Les Climats du Cameroun", TomeIII [Ph.D. thesis], Université de St Etienne, St. Etienne, France, 1987.

[5] J. C. Olivry, "Fleuves et rivières du Cameroun," in Monographies Hydrologiques ORSTOM, ORSTOM, Marseille, France, 1986.

[6] X. Yongxin and B. Usher, Groundwater Pollution in Africa, Taylor \& Francis e-Library, 2006.

[7] S. S. Betah, "Complement sur la monographe nationale de l'eau (aspects eaux souterrraines)," in Ministère des Mines et Energie, Yaoundé, Cameroon, 1976.

[8] H. B. Djeuda Tchapnga, "Géologie et hydrologie d'un secteur de la zone mobile d’Afrique Centrale: région de Poli, NordCameroun," Presse Universitaire Yaoundé I, Yaoundé, Cameroun, 1987.

[9] M. Lasserre, "Carte géologique de reconnaissance à l'échelle 1/ 500 000, territoire du Cameroun, ngaoundéré-est," Dir, Mines Géol. Cameroun, Yaoundé, Cameroun, 1961.

[10] S. F. Toteu, W. R. Van Schmus, J. Penaye, and A. Michard, "New U-Pb and Sm-Nd data from north-central Cameroon and its bearing on the pre-Pan African history of Central Africa," Precambrian Research, vol. 108, no. 1-2, pp. 45-73, 2001.

[11] S. F. Toteu, J. Penaye, and Y. P. Djomani, "Geodynamic evolution of the Pan-African belt in central Africa with special reference to Cameroon," Canadian Journal of Earth Sciences, vol. 41, no. 1, pp. 73-85, 2004.

[12] A. A. Ganwa, W. Siebel, W. Frisch, and C. K. Shang, "Geochemistry of magmatic rocks and time constraints on deformational phases and shear zone slip in the Méiganga area, central Cameroon," International Geology Review, vol. 53, no. 7, pp. 759784, 2011.

[13] G. A. Alexandre, S. Wolfgang, S. K. Cosmas, N. Seguem, and E. G. Emmanuel, "New Constraints from Pb-Evaporation Zircon Ages of the Méiganga Amphibole-Biotite Gneiss, Central Cameroon, on Proterozoic Crustal Evolution," International Journal of Geosciences, vol. 2, no. 2, pp. 138-147, 2011.

[14] D. Baise, "Guide pour la Description des Sols," in Institut National de la Recherche Agronomique, France, Paris, 1995.

[15] A. A. Ganwa, W. Frisch, W. Siebel, G. E. Ekodeck, C. K. Shang, and V. Ngako, "Archean inheritances in the pyroxene-amphibole-bearing gneiss of the Méiganga area (Central North Cameroon): Geochemical and ${ }^{207} \mathrm{~Pb} /{ }^{206} \mathrm{~Pb}$ age imprints," Comptes Rendus Geoscience, vol. 340, no. 4, pp. 211-222, 2008.

[16] M. Lazzari, E. Geraldi, V. Lapenna, and A. Loperte, "Natural hazards vs human impact: An integrated methodological approach in geomorphological risk assessment on the Tursi historical site, Southern Italy," Landslides, vol. 3, no. 4, pp. 275287, 2006.

[17] O. Sass, R. Bell, and T. Glade, "Comparison of GPR, 2D-resistivity and traditional techniques for the subsurface exploration of the Öschingen landslide, Swabian Alb (Germany)," Geomorphology, vol. 93, no. 1-2, pp. 89-103, 2008.

[18] D. H. Griffiths and R. D. Barker, "Two-dimensional resistivity imaging and modelling in areas of complex geology," Journal of Applied Geophysics, vol. 29, no. 3-4, pp. 211-226, 1993.

[19] M. Ritz, J.-C. Parisot, S. Diouf, A. Beauvais, F. Dione, and M. Niang, "Electrical imaging of lateritic weathering mantles over granitic and metamorphic basement of eastern Senegal, West Africa," Journal of Applied Geophysics, vol. 41, no. 4, pp. 335344, 1999.

[20] D. H. Robert and D. K. William, An Introduction to Geotechnical Engineering, Prentice Hall, Englewood Cliffs, NJ, USA, 1981.

[21] F. G. Bell, Fundamentals of Engineering Geology, Butterworth and Co., London, UK, 1983.

[22] D. Kumar, "Efficacy of electrical resistivity tomography technique in mapping shallow subsurface anomaly," Journal of the Geological Society of India, vol. 80, no. 3, pp. 304-307, 2012.

[23] M. I. I. Mohamaden, S. Abuo Shagar, and G. A. Allah, "Geoelectrical survey for groundwater exploration at the Asyuit governorate, Nile Valley, Egypt," Journal of King Abdulaziz University, Marine Science, vol. 20, no. 1, pp. 91-108, 2009.

[24] M. I. I. Mohamaden, A. Wahaballa, and H. M. El-Sayed, "Application of electrical resistivity prospecting in waste water management: A case study (Kharga Oasis, Egypt)," Egyptian Journal of Aquatic Research, vol. 42, no. 1, pp. 33-39, 2016.

[25] A. G. A. Hewaidy, E. A. El-Motaal, S. A. Sultan, T. M. Ramdan, A. A. El khafif, and S. A. Soliman, "Groundwater exploration using resistivity and magnetic data at the northwestern part of the Gulf of Suez, Egypt," Egyptian Journal of Petroleum, vol. 24, no. 3, pp. 255-263, 2015.

[26] H. Tigistu and A. Alemayehu, "Electrical resistivity tomography and magnetic surveys: applications for building site characterization at Gubre, Wolkite University site, western Ethiopia," Ethiopian Journal of Science and Technology, vol. 37, no. 1, pp. 13-30, 2014.

[27] O. Sass, "Determination of the internal structure of alpine talus deposits using different geophysical methods (Lechtaler Alps, Austria)," Geomorphology, vol. 80, no. 1-2, pp. 45-58, 2006.

[28] L. Schrott and O. Sass, "Application of field geophysics in geomorphology: Advances and limitations exemplified by case studies," Geomorphology, vol. 93, no. 1-2, pp. 55-73, 2008.

[29] D. S. Parasnis, Principles of Applied Geophysics, Chapman and Hall, London, UK, 5th edition, 1997.

[30] R. D. Barker, "The offset system of electrical resistivity sounding and its use with a multicore cable," Geophysical Prospecting, vol. 29, no. 1, pp. 128-143, 1981.

[31] Y. Vichabian and F. D. Morgan, Self-Potentials in Cave Detection, Massachusetts Institute of Technology, Cambridge, Mass, USA, 2002.

[32] M. M. Smoluchowski, "Contribution à la théorie de lendosmose électrique et de quelques phénomènes corrélatifs," Bulletin de l'Académie des Sciences de Cracovie, pp. 182-200, 1903.

[33] H. L. Kandé, Etude Géophysique de la structure de la croute le long du Fossé Tectonique de la Mbéré (Sud Adamaoua-Cameroun) [Ph.D. thesis], University of Yaoundé I, Yaoundé, Cameroon, 2008. 
[34] M. H. Loke and T. Dahlin, "A comparison of the Gauss-Newton and quasi-Newton methods in resistivity imaging inversion," Journal of Applied Geophysics, vol. 49, no. 3, pp. 149-162, 2002.

[35] T. Dahlin and M. H. Loke, "Resolution of 2D Wenner resistivity imaging as assessed by numerical modelling," Journal of Applied Geophysics, vol. 38, no. 4, pp. 237-249, 1998.

[36] M. H. Loke and R. D. Barker, "Rapid least-squares inversion of apparent resistivity pseudosections by a quasi-Newton method," Geophysical Prospecting, vol. 44, no. 1, pp. 131-152, 1996.

[37] K. Sudha, M. Israil, S. Mittal, and J. Rai, "Soil characterization using electrical resistivity tomography and geotechnical investigations," Journal of Applied Geophysics, vol. 67, no. 1, pp. 74-79, 2009.

[38] E. T. Faleye and G. O. Omosuyi, "Geophysical and geotechnical characterization of foundation beds at Kuchiyaku, Kuje area, Abuja, Nigeria," Journal of Emerging Trends in Engineering and Applied Sciences, vol. 2, no. 5, pp. 864-870, 2011. 

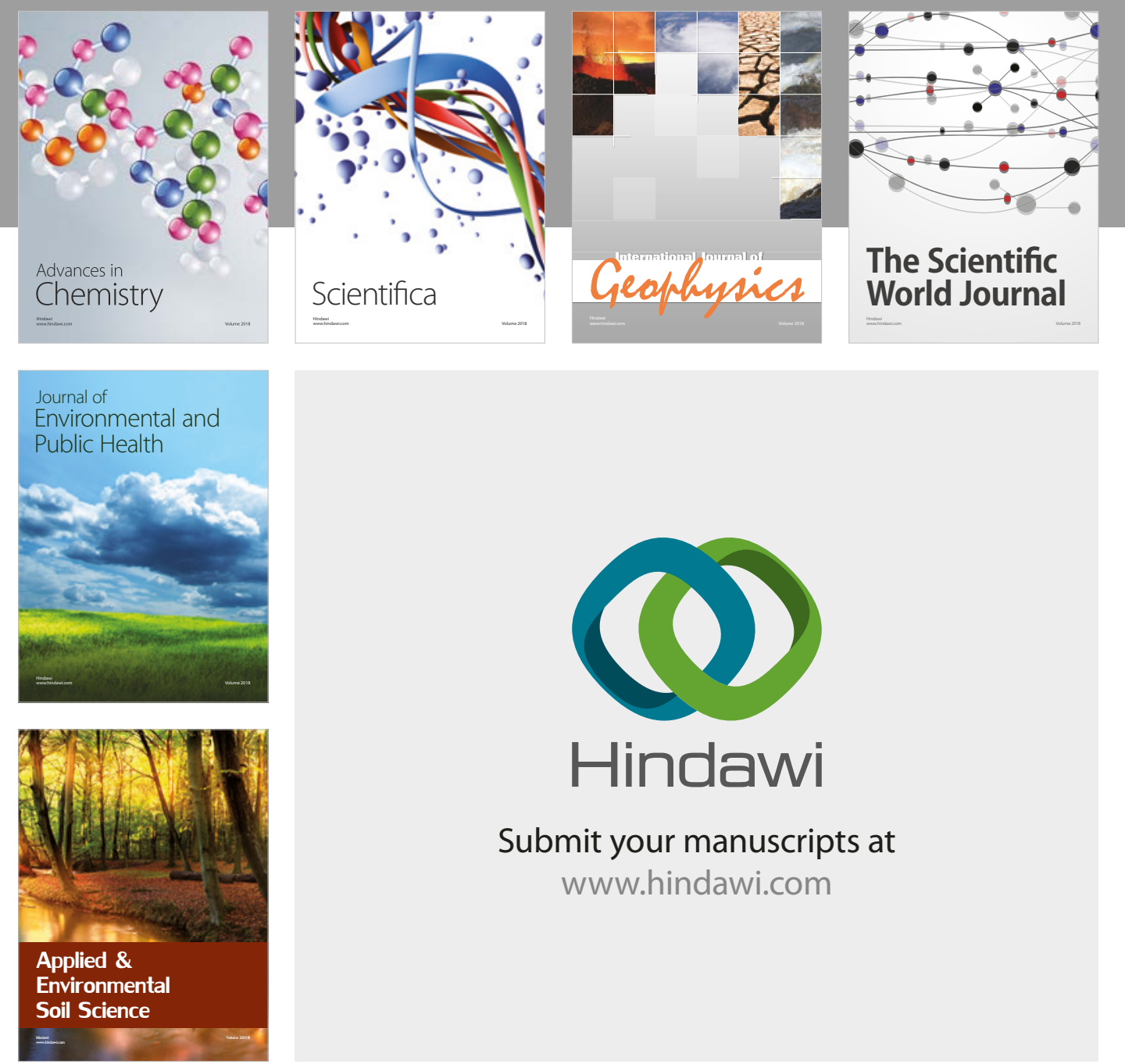

The Scientific

\section{World Journal}
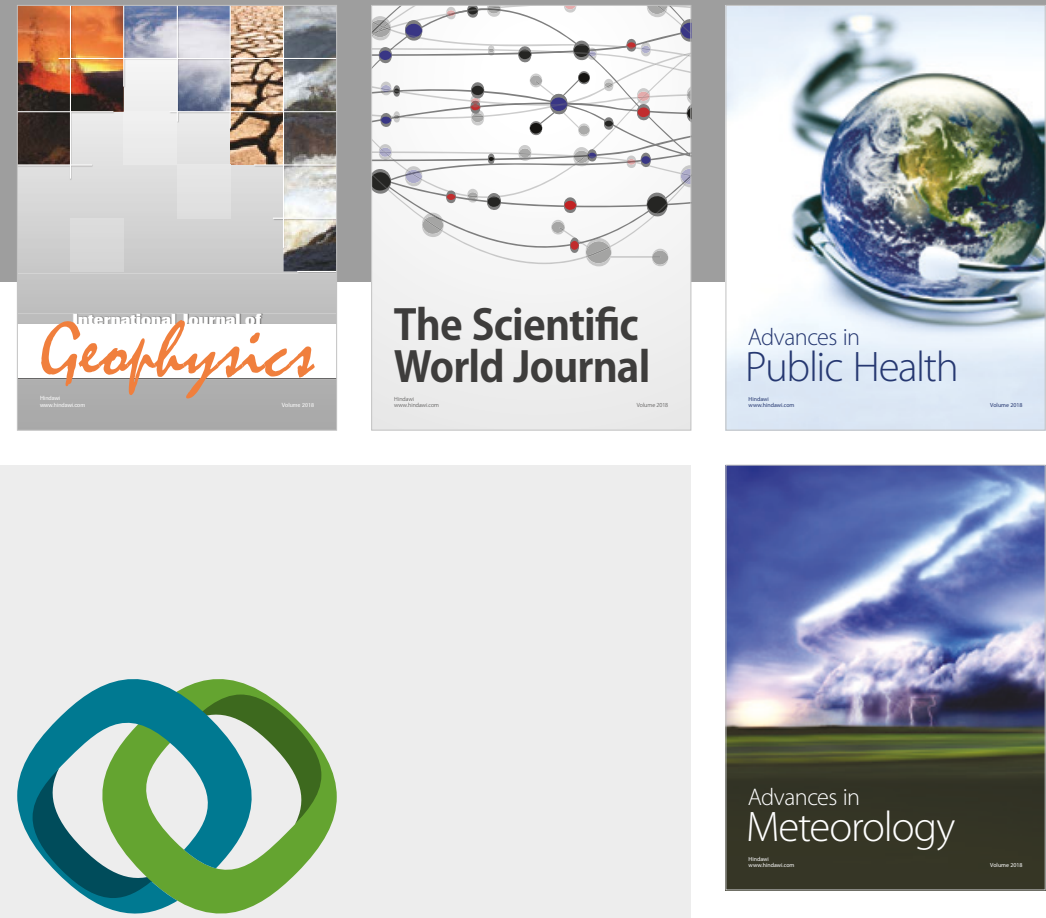

Advan

Public Health

\section{Hindawi}

Submit your manuscripts at

www.hindawi.com
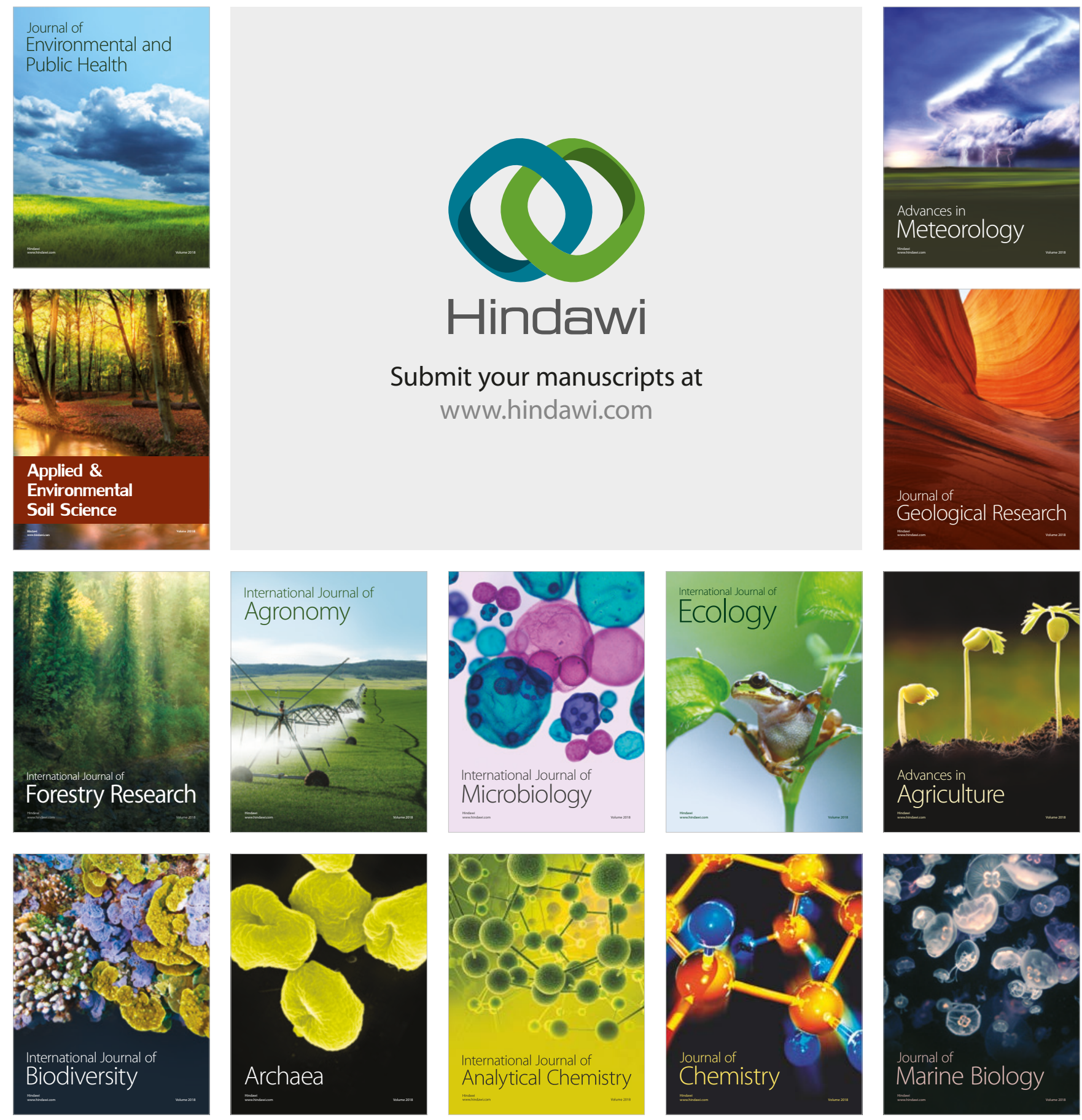